\title{
PROVISIONING FOOD GIVEN BY VISITORS TO ALPHA-MALE LONG-TAILED MACAQUES AT RECREATION FOREST, ALL OF THEM ARE HALAL
}

\author{
MAKANAN DARI PENGUNJUNG YANG DIBERIKAN KEPADA JANTAN ALFA \\ MONYET EKOR PANJANG DI TAMAN REKREASI, SEMUANYA HALAL
}

Received: 20/04/2021; Revised: 28/10/2021; Accepted: 11/11/2021; Published: 30/11/2021

\author{
Rosyid Ridlo Al Hakim $1, *$, Erie Kolya Nasution ${ }^{2}$, Rizaldi ${ }^{3}$, Siti Rukayah ${ }^{2}$ \\ ${ }_{1}^{1}$ Primatology Study Program, Graduate School, IPB University, Bogor, Indonesia \\ ${ }^{2}$ Department of Environmental Biology, Faculty of Biology, Universitas Jenderal Soedirman, \\ Purwokerto, Indonesia \\ ${ }^{3}$ Department of Biology, Faculty of Mathematics and Natural Sciences, Andalas University, Padang, \\ Indonesia \\ *Corresponding author: alhakimrosyid@apps.ipb.ac.id
}

\begin{abstract}
The long-tailed macaque (Macaca fascicularis Raffles, 1821) is a non-human primate (NHP) species with social status in its group. Macaca fascicularis living in groups and social castes. Alpha males lead their group. Alpha males will have greater access to food than individuals with lower social castes. The content of feed eaten by animals, of course, will affect health. Various biological processes occur, from the food eaten by animals to affect the health of human life. If the food eaten is toxic, it will be hazardous to the animal's metabolism for life. According to a Muslim perspective, how much better food can be eaten is included in Halal products. Including, in this case, food ingredients for feed, if it comes from ingredients that are included in the halal category, this will provide animal welfare. This study seeks to explain how visitors' feed types (provisioning food) to alpha-male Macaca fascicularis at Mbah Agung Karangbanar Recreation Forest, Banyumas, Central Java, Indonesia. This study used behavioral coding to measure the frequency and quantity of eating behavior for ten days based on visitor feeding. The remainder of the provisioning food found is recorded as data on the type of provisioning food. Based on the study results, the alpha-male was noted to eat provisioning food such as peanuts, bananas, sweet potatoes, snacks, and foods mixed with soy sauce given by visitors. All of them are halal because they eat visitors every time they come to a tourist location. Alpha-male was noted to have no interest in the carcasses found, so they did not eat them.
\end{abstract}

Keywords: anthropogenic food, eating behavior, ethnoprimatology, human-primate interaction, Macaca fascicularis.

\begin{abstract}
ABSTRAK
Kera ekor panjang (Macaca fascicularis Raffles, 1821) merupakan jenis primata non-manusia (NHP) yang berstatus sosial dalam kelompoknya. Macaca fascicularis hidup berkelompok dan kasta sosial, kelompoknya dipimpin oleh jantan alfa. Laki-laki alfa akan memiliki akses yang lebih besar ke makanan daripada individu dengan kasta sosial yang lebih rendah. Kandungan pakan yang dimakan hewan, tentunya akan mempengaruhi kesehatan. Berbagai proses biologi yang terjadi, dari makanan yang dimakan hewan hingga mempengaruhi kesehatan kehidupan manusia. Jika makanan yang dimakan beracun maka akan sangat berbahaya bagi metabolisme hewan tersebut seumur hidupnya. Alangkah baiknya, menurut perspektif Muslim, makanan yang bisa dimakan ini termasuk dalam kategori produk halal. Termasuk dalam hal ini bahan pangan untuk pakan, jika berasal dari bahan yang termasuk dalam kategori halal maka akan memberikan kesejahteraan bagi hewan. Penelitian ini berusaha menjelaskan bagaimana jenis pakan yang diberikan pengunjung kepada jantan alfa Macaca fascicularis di TWR Makam Mbah Agung Karangbanar, Banyumas, Jawa Tengah, Indonesia. Penelitian ini menggunakan metode pencatatan frekuensi dan kuantitas tingkah laku makan selama 10 hari berdasarkan pemberian makan pengunjung. Sisa pakan yang ditemukan dicatat sebagai data jenis makanan. Hasil penelitian, jantan alfa memakan kacang goreng, pisang, ubi jalar, makanan
\end{abstract}


ringan, dan makanan mengandung kecap yang diberikan pengunjung dan semuanya halal karena dimakan juga oleh pengunjung setiap datang ke lokasi wisata. Jantan alfa tak tertarik dengan bangkai yang ditemukan dan tak memakannya.

Kata kunci: etnoprimatologi, interaksi manusia-primata, Macaca fascicularis, pakan antropogenik, tingkah laku makan.

How to cite: Hakim, RRA., Nasution, EK., Rizaldi, Rukayah, S. 2021. Provisioning Food Given by Visitors to Alpha-Male Long-Tailed Macaques at Recreation Forest, All of Them are Halal. Journal of Halal Product and Research. 4(2), 50-58, https://dx.doi.org/10.20473/jhpr.vol.4-issue.2.50-58.

\section{INTRODUCTION}

The long-tailed macaques (Macaca fascicularis Raffles, 1821) is a non-human primate (NHP) species that has the social caste status in its group (Gursky-Doyen \& Supriatna 2010; Rowe \& Myers 2016; Strier 2017). The habitat of Macaca fascicularis is very widespread in various regions, but the prior status issued by IUCN is vulnerable. Because Macaca fascicularis has a high level of tolerance to habitat change, it causes Macaca fascicularis to have an extensive distribution, including Bangladesh, Brunei, Cambodia, India (Nicobar Islands), Indonesia (Bali, Bangka, the Batu Islands, Bawean, Belitung, Java, Kalimantan Borneo, the Kangean Islands, Karimata, Karimunjawa, Lingga, Lombok, the Natuna Islands, Nias, Nusa Tenggara, the Riau Archipelago, Simeulue, Sumatra, Sumba, Sumbawa, and Timor), Lao PDR, Malaysia (including the Peninsula as well as Sabah and Sarawak Borneo), Myanmar (including the Mergui Archipelago), the Philippines (Balabec, Basilan, Cagayan Sulu, Culion, Jolo, Leyte, Luzon, Mindanao, Mindoro, Palawan, and Samar), Singapore, Thailand (including offshore islands), Timor-Leste and Viet Nam (Eudey et al., 2020).

Long-tailed macaques are reported to live more frequently in the forest with the changes that occur. Among them are close to the local human habitat (Richard et al., 1989; Tsuji \& llham, 2021) and feeding when the Macaca fascicularis habitat is in a tourist park location, for example, which allows for more frequent interaction with humans (human-primate interaction) (Brotcorne et al., 2020; Gruber et al., 2019; Gursky-Doyen \& Supriatna, 2010; Ilham et al., 2017; Tsuji \& Ilham, 2021). Gogoi \& Das (2018) reported feeding a group of Macaca fascicularis at Navagraha Temple, Kamrup district of Assam, India, recorded daily for 2-4 hours, with the type of feeding given to visitors in the form of snacks, bananas, biscuits, cakes, chips. Similar reports were reported by Nila et al. (2014) with different locations, in Telaga Warna, Bogor, West Java, Indonesia, that the highest feeding rates for Macaca fascicularis were peanuts $(19.8 \%)$, bananas $(18.4 \%)$, biscuits $(5 \%)$, snacks $(4.1 \%)$, cakes ( $2 \%$ ), chips $(1.7 \%)$. The habit of visitors to provide food to certain animals, including Macaca fascicularis, has reasons to attract their attraction so that they approach humans or reasons such as humans who want to see it from a very close distance, to observe their behavior afterward (de Waal 2002). People who habit to giving food (also called anthropogenic food, provisioning food, artificial food) to primates also known as human-primate interaction in ethnoprimatology study (Hadi et al. 2007; Sengupta \& Radhakrishna 2018).

Nasution and Rukayah (2018) reported the frequency of feeding adult male Macaca fascicularis at Cikakak Tourist Resort Wangon Banyumas (a Conservation Effort), Central Java, Indonesia ranks third in the percentage of their daily activity observed. Feeding is at a percentage of $10.24 \%$ for adult males every day (the highest is resting $47.28 \%$, followed by walking $21.28 \%$ ). Interestingly, there is no reported activity of looking for food for the adult male $(0 \%)$, so that the food is eaten comes from visitors, not purely looking for food himself. Because Macaca fascicularis is a non-human primate (NHP) species living in groups and social castes, their group is led by alpha males. Alpha males will have greater access to food than individuals with lower social castes (Gursky-Doyen \& Supriatna, 2010; Hidayat et al., 2019; Koda et al., 2012; Mardiah et al., 2015; Rizaldi \& Watanabe, 2008, 2010; Rowe \& Myers, 2016).

The content of feed eaten by animals, of course, will affect health. Various biological processes occur, from the food eaten by animals to affect the health of human life (Sapkota et al., 2007). If the food eaten is toxic, it will be hazardous to the animal's metabolism for life. The content of food eaten by animals will significantly determine the digestive conditions and even the health of the animals themselves. Diseases that arise from the contaminated animal feed with toxic substances will ultimately affect the environment (ve Meijer, 2007; Verstraete, 2013). According to a Muslim perspective, how much better food can be eaten is included in Halal products. Including, in this case, food ingredients for feed, if it comes from ingredients that are included in the halal category, this will 
provide animal welfare because it is inevitable that halal ingredients will not endanger the health of the animal itself (Ashraf \& Rahman, 2018).

Based on the feeding conditions at Mbah Agung Karangbanar Recreation Forest, Banyumas, Central Java, Indonesia, and what types of food are provided by visitors in the Macaca fascicularis group, in this case, the group leader is alpha-male. Visitors do feeding by visitors, including types of halal foods. How alpha-male Macaca fascicularis looks for food at the observation site when feeding, what is chosen to eat, not all feedings are accepted by alpha-male. Therefore, this study aims to explain how the types of feed given by visitors to alpha-male Macaca fascicularis at Mbah Agung Karangbanar Recreation Forest.

\section{RESEARCH METHOD}

\section{Study Sites}

The study was conducted between July and December 2020 in Mbah Agung Karangbanar Recreation Forest (locally known as Makam Kramat Karangbanar), Kalisalak sub-district, Kebasen district, Banyumas regency, Central Java, Indonesia, with location coordinates -7.5315027 and 109.2346672, which; the recreation forest type is the evergreen forest that coexisted between human and long-tailed macaque. This study focuses on focal animals (focal animal sampling) (Altmann 1974) as the subject for observation is the alpha-male Macaca fascicularis at the study site. Observations were carried out for ten days, with each day starting at 08:00 and ending at 17:00. Each time, there is an observation session (interval), which is divided into 15 minutes. So that within ten days of observation, a total of 32 intervals were obtained. The study site can be seen in Figure 1.

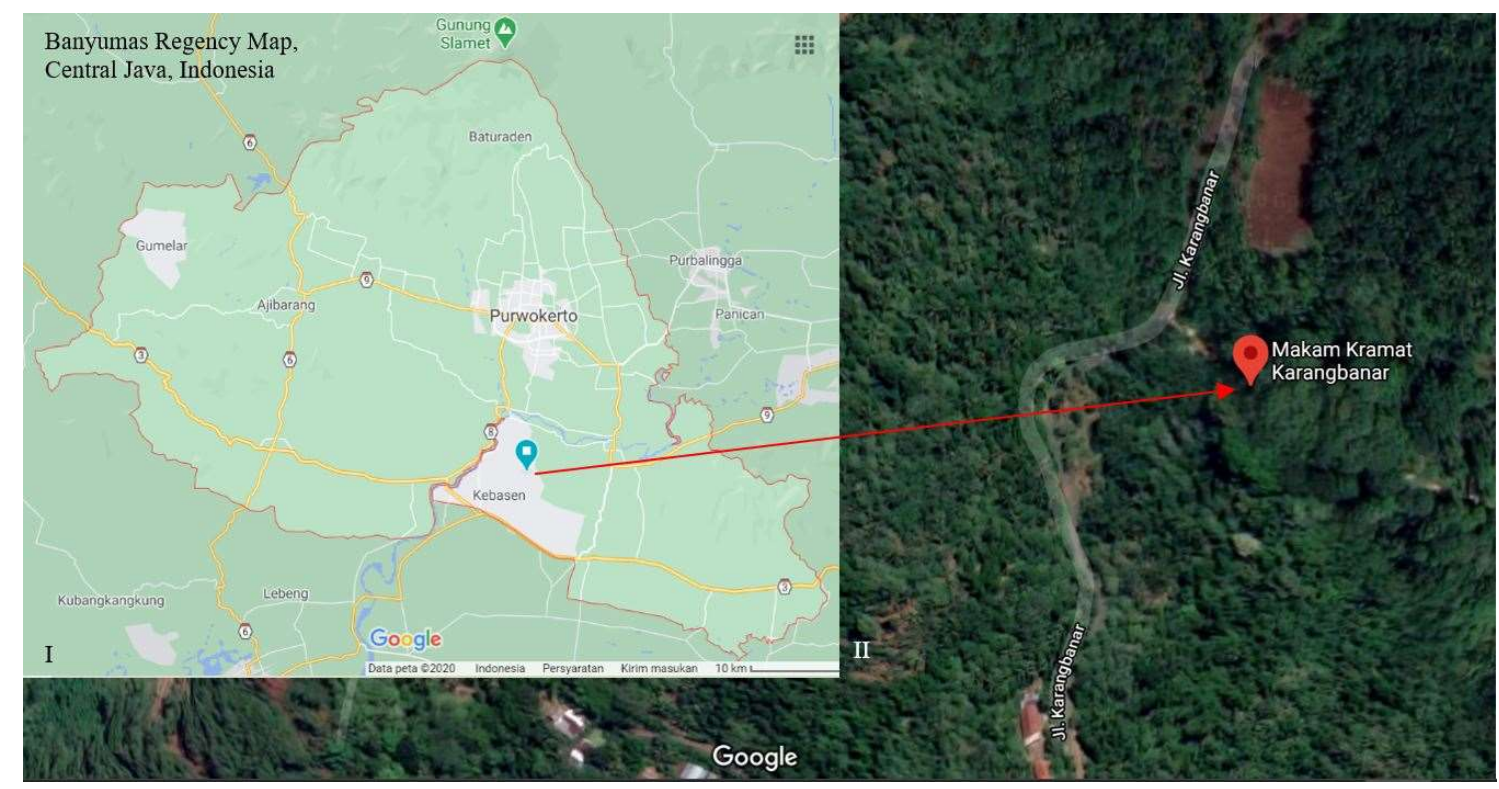

Figure 1. Study sites of this research (locally known as Makam Kramat Karangbanar). Source: Google Maps, 2020.

\section{Data Analysis}

This study used behavioral coding to measure the frequency and quantity of feeding behavior for ten days based on visitor feeding (provisioning food). The remainder of the provisioning food found is recorded as data on the type of provisioning food. Recorded categories and types of feed are shown in the graphic diagram.

\section{RESULT AND DISCUSSION}

\section{Alpha-male Only Eats Halal Food Provisioning}

During the observation, the alpha-male Macaca fascicularis carried out feeding activities based on provisioning food given by visitors 157 times. This provisioning food activity is carried out whenever visitors come to tourist sites and provide food to Macaca fascicularis, and alpha-male as group leaders who always succeed in getting the first time provisioning food. The feeding activity of alpha-male provisioning food during the 10-day observation can be seen in Figure 2 . 


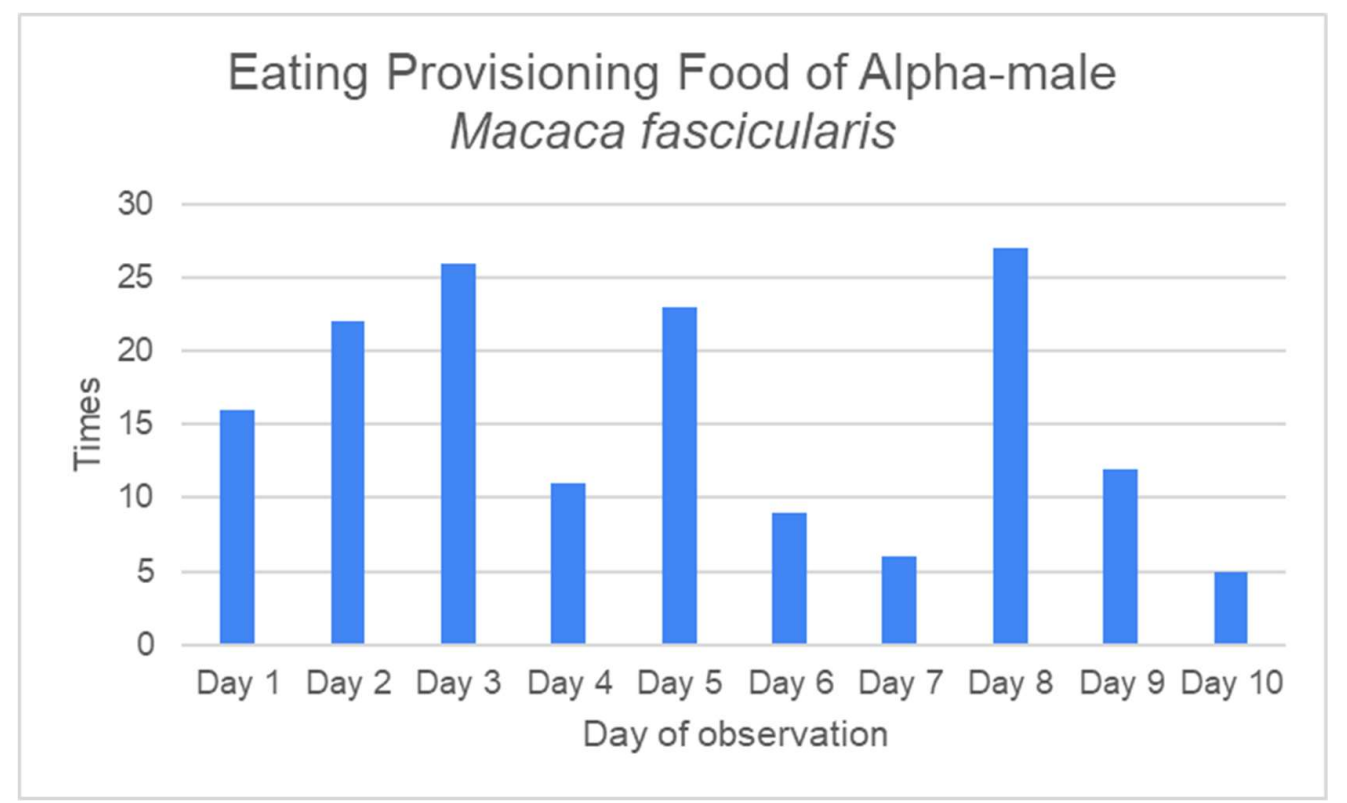

Figure 2. Alpha-male activity in feeding provisioning food from visitors. Source: data obtained.

Based on Figure 2, the total number of eating provisioning food is 157 (total maximum party size, which indicates the total amount of provisioning food preference in some habitats for all groups), as shown in Table 1. The provisioning food that the alpha-male ate consisted of peanuts (fried, kacang goreng), bananas, sweet potatoes (ubi jalar), snacks (makanan ringan), and foods mixed with soy sauce (such as the provisions the researchers brought to eat, some were given to the alphamale). Another site reported that the total provisioning food in Cikakak Monkey Park, Banyumas Regency, Central Java is 98 (total maximum party size). That site was categorized as semiprovisioned habitat (Hadi et al. 2007).

Table 1. The number of total eating provisioning food.

\begin{tabular}{lllllll}
\hline & Peanut & Banana & Sweet potato & Snack & Foods mixed with soy sauce & Total \\
\hline Day 1 & 16 & 0 & 0 & 0 & 0 & 16 \\
\hline Day 2 & 6 & 10 & 4 & 2 & 0 & 22 \\
\hline Day 3 & 13 & 4 & 3 & 5 & 1 & 26 \\
\hline Day 4 & 5 & 0 & 0 & 3 & 3 & 11 \\
\hline Day 5 & 16 & 4 & 3 & 0 & 0 & 23 \\
\hline Day 6 & 9 & 0 & 0 & 0 & 0 & 9 \\
\hline Day 7 & 3 & 0 & 3 & 0 & 0 & 6 \\
\hline Day 8 & 10 & 2 & 7 & 5 & 3 & 27 \\
\hline Day 9 & 6 & 4 & 0 & 2 & 0 & 12 \\
\hline Day 10 & 5 & 0 & 0 & 0 & 0 & 5 \\
\hline
\end{tabular}

Source: data obtained.

With such a large number, we try to map the distribution of food from visitors. The distribution of the types of provisioning food eaten by alpha-male can be seen in Figure 3. 


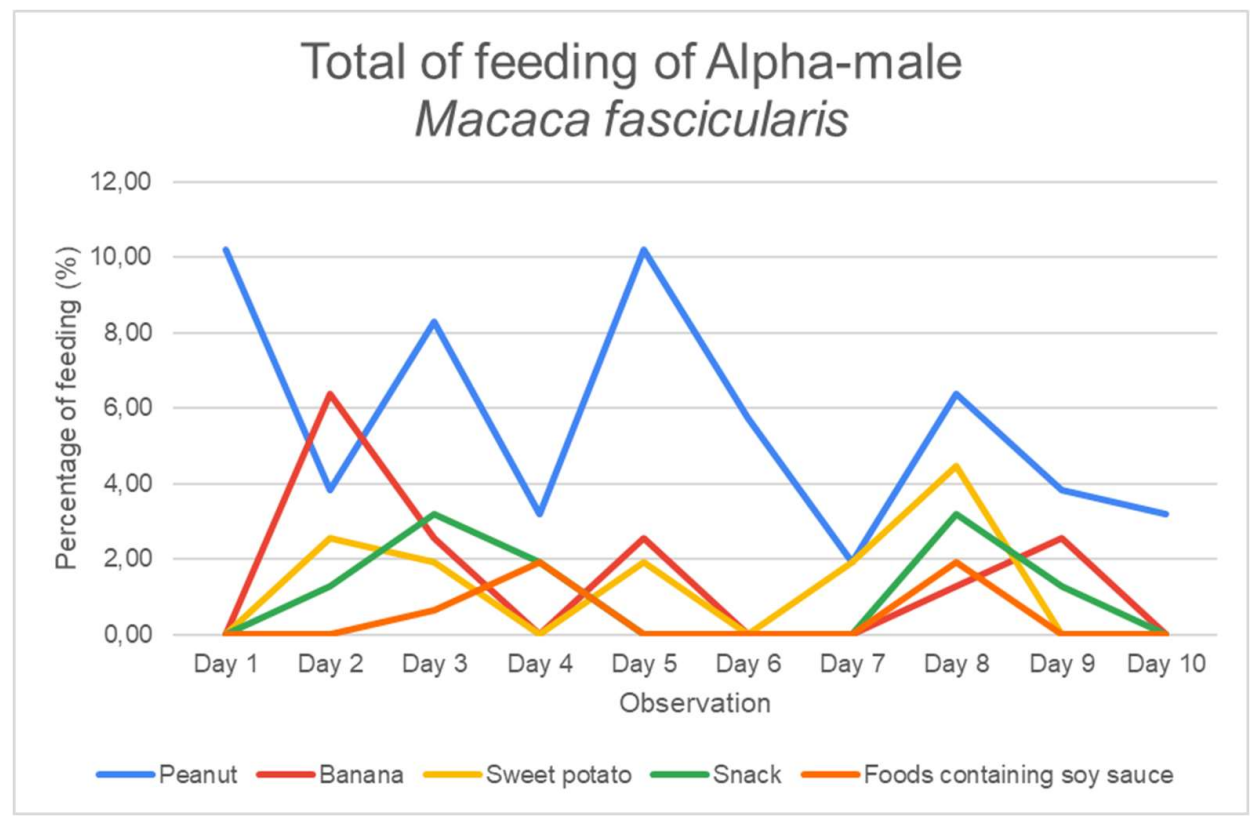

Figure 3. Percentage of food from several types of provisioning food. Source: data obtained.

Based on Figure 3, the alpha-male only ate provisioning food such as peanuts, banana, sweet potato, snacks, and foods containing soy sauce. There are five types of provisioning food that, when viewed in content, come from cooked food. During the observation, visitors were frequently seen giving peanuts. Documentation of visitors giving peanuts to alpha-male and troops of Macaca fascicularis can be seen in Figure 4.

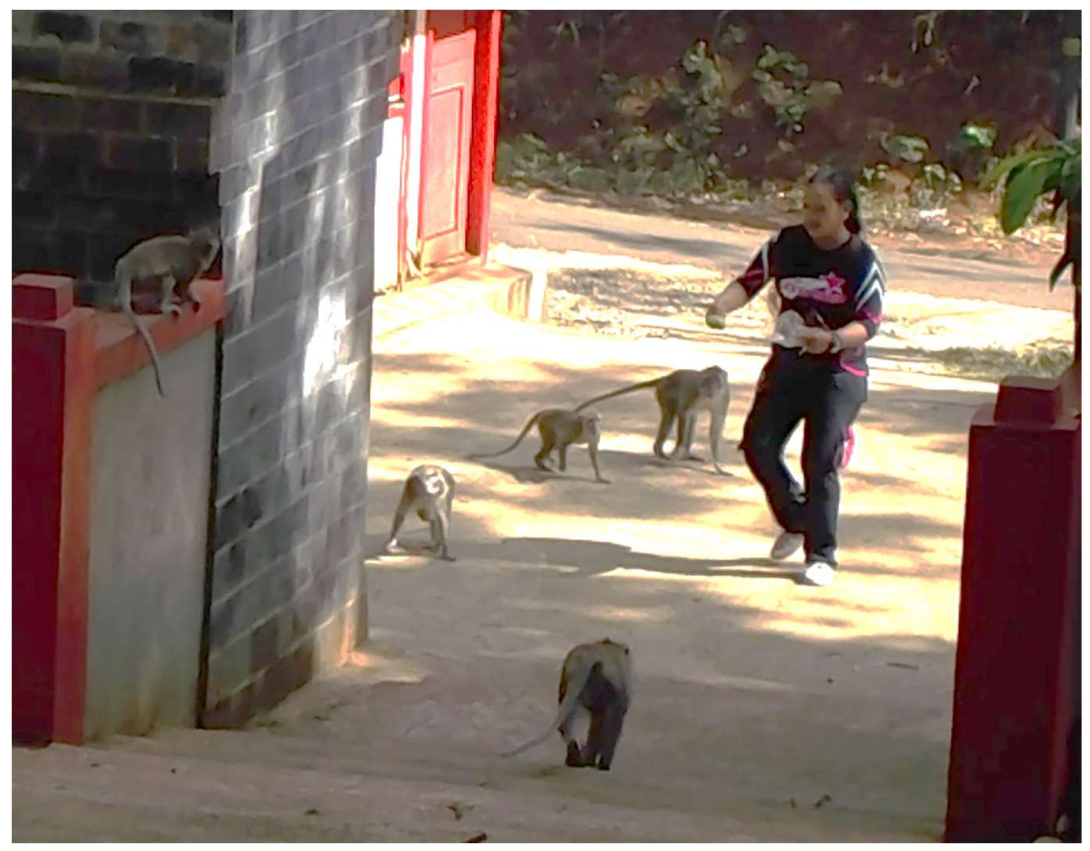

Figure 4. Feeding by visitors to Macaca fascicularis.

Source: researcher documentation.

Based on Figure 4, a visitor can be seen giving peanuts to a group of Macaca fascicularis during the observation. The cooking-type of provisioning food such as fried or boiled, in this case, the preference of provisioning foods are peanut, banana, sweet potatoes, snack, foods mixed with soy sauce, can be categorized in fried and boiled food-the fried food, including peanut, snack, and foods mixed with soy sauce-furthermore, the boiled food including sweet potatoes. The process of 
cooking-type of fried provisioning food such as peanut comes from peanuts obtained from traditional markets and then fried at home, and ends up in small home-based shops that are sold. This argument is based on an interview with a food seller near the recreation forest. Even visitors bought some provisioning food there; we also interviewed some visitors who bring the provisioning food for longtailed macaque.

On the other hand, foods mixed with soy sauce also come from home fryers, generally food supplies for visitors. Furthermore, the snack that is fed to alpha-male is labeled halal. Most types of snacks on the market have a halal label because the area around the recreational forest is dominated by Muslim communities (based on secondary data from the local government) (Quantaniah et al. 2013). Muslim people will also prefer snack products with halal labels (Efendi et al. 2019; Randeree 2019). They will look at the food ingredients listed on the packaging, whether it supports halal products or vice versa (Al-Teinaz 2020).

The habit of visitors when they come to the recreation forest, which always provides provisioning food, has been memorized by the Macaca fascicularis troops. Once we arrived at the location, we were greeted by Macaca fascicularis and led by alpha-male when approached. They did not hesitate to wait to provision food. Alpha-male is noted to receive frequent provisioning food, especially peanuts. Nuts often found from alpha-male leftovers, including fried peanuts $\left(\sum=89\right.$, highest provisioning food), are halal because humans can also consume them. Alpha-male eating peanuts from the results of provisioning food by visitors can be seen in Figure 5.

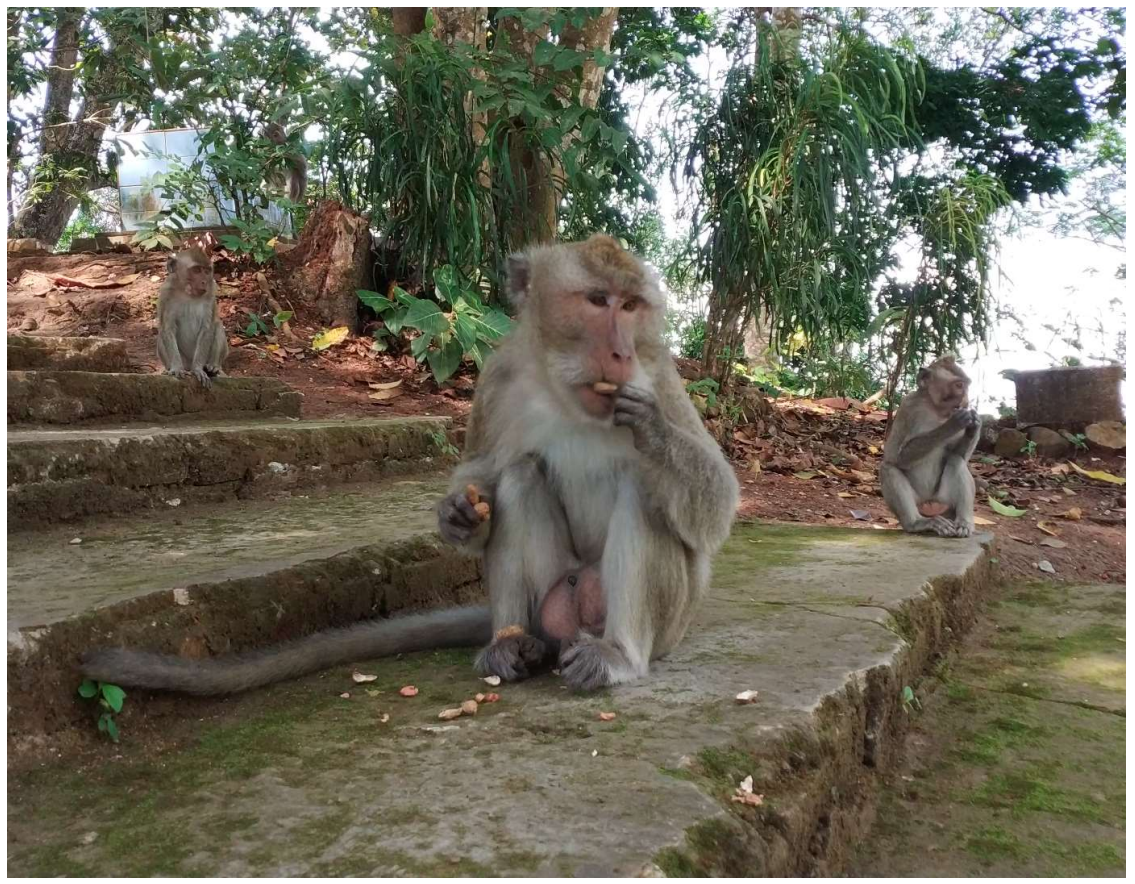

Figure 5. Alpha-male is eating the peanuts the visitor gave him. Source: researcher documentation.

The second highest type of provisioning food is bananas. These bananas are obtained from visitors who come. Of course, visitors do not eat the bananas they bring, even though they are halal and edible while visiting tourist sites. Still, they deliberately provide ripe whole bananas that are given to the Macaca fascicularis group, and of course, as alpha-male, must be the first to get them. An alpha-male eating a ripe banana can be seen in Figure 6. Bananas are derived from agricultural food, like sweet potatoes, derived from the farmer (Jefferies et al. 2004; Hockings \& McLennan 2012; Vávra et al. 2018). Agricultural food is generally processed in a halal manner, and it is rare to find cases of najs in the agricultural process. 


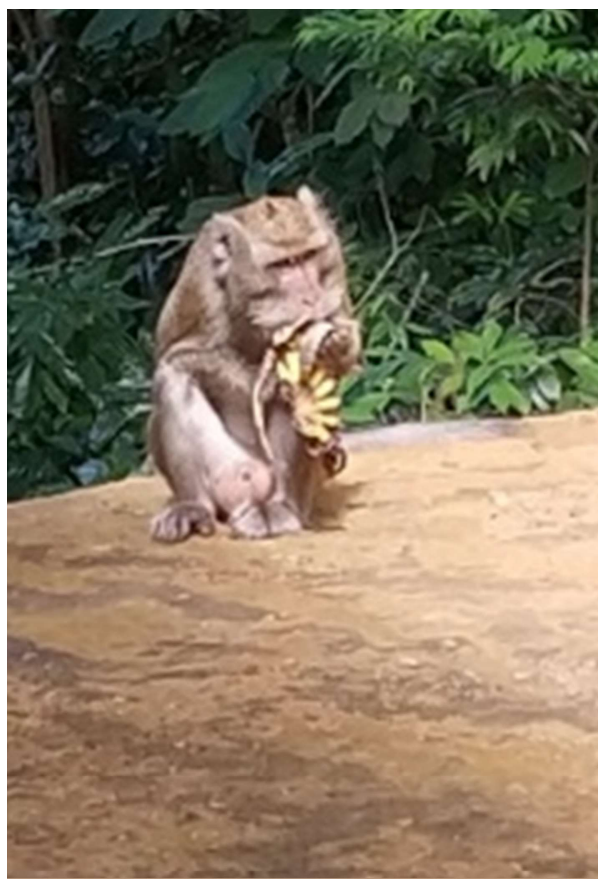

Figure 6. Alpha-male feeding banana from a visitor. Source: researcher documentation.

Apart from peanuts and bananas, visitors gave the alpha-male and Macaca fascicularis troops including sweet potatoes that humans, including halal, could eat. Also, we tried to bring snacks and food supplies, including foods mixed with soy sauce. Of course, this is halal because several Macaca fascicularis approached us, so we gave food to them, including the alpha-male who led the group. We found a carcass during the observation, but alpha-male and others were reluctant to approach it, let alone eat it. According to lqbal et al. (2019), carcasses are included as najs, dangerous, and are not allowed to be consumed, not halal (haram). Besides, alpha-male do not approach the carcass at all, even with a facial expression of disgust when passing it.

The habits of visitors who provide this food can undoubtedly affect the health of the animal itself. According to Maréchal et al. (2016), provisioning food may overall have negative impacts on the health of wildlife (including long-tailed macaque); it has been linked in particular to larger body size and elevated stress levels, and more alopecia. Besides, some cases of pathogen transmission to humans are linked to macaques based on human-primate interaction (Fuentes 2006). In addition to health, the impact on behavior, habitat use, and human-primate conflict can be seen from the animals used to getting artificial or provisioning food (Sha \& Hanya 2013; llham et al. 2018). The health benefit of nutrition from provisioning food such as fiber and protein (Korkerd et al. 2015) can also be seen from the body posture of the long-tailed macaque (alpha-male and troops), which still looks ideal, not too thin, not fat. Further research is needed to record the natural food consumed to be compared with the provisioning food data.

\section{CONCLUSION}

Alpha-male was noted to eat provisioning food such as peanuts, bananas, sweet potatoes, snacks, and foods mixed with soy sauce, all of which are halal. Alpha-male was noted to have no interest in the carcasses found, so they did not eat them. The body posture of alpha-male and troops looks ideal but needs further research to compare between natural food and provisioning food.

\section{ACKNOWLEDGEMENTS}

The author would like to thank the Faculty of Biology, Universitas Jenderal Soedirman, for supporting the smooth running of this research. Furthermore, the first author is always motivated by Dian Sulistyaningrum to continue to carry out observations and research well. Very lucky! 


\section{REFERENCES}

Al-Teinaz YR. 2020. Halal Ingredients in Food Processing and Food Additives. Halal Food Handb:149-167.

Altmann J. 1974. Observational Study of Behavior: Sampling Methods. Behaviour. 49(3-4):227-266.

Brotcorne F, Holzner A, Jorge-Sales L, Gunst N, Hambuckers A, Wandia IN, Leca JB. 2020. Social influence on the expression of robbing and bartering behaviours in Balinese long-tailed macaques. Anim Cogn. 23(2):311-326.

De Waal FBM. 2002. Tree of Origins: What Primate Behavior Can Tell Us About Human Social Evolution. New York: Harvard University Press.

Efendi R, Sukidjo, Indartono S. 2019. The Factor of Intention to Buy Snacks Labeled Halal on Muslim Students in Yogyakarta. IQTISHADIA. 12(2):211-226.

Eudey A, Kumar A, Singh M, Boonratana R. 2020. Macaca fascicularis. The IUCN Red List of Threatened Species 2020: e.T12551A17949449.

Fuentes A. 2006. Human culture and monkey behavior: Assessing the contexts of potential pathogen transmission between macaques and humans. Am J Primatol. 68(9):880-896.

Gogoi S, Das AN. 2018. Periodic Research Diet and Feeding Behaviour of Rhesus Macaque at Navagraha Temple , Kamrup district of Assam. Period Res. 7(2):93-98.

Gruber T, Luncz L, Mörchen J, Schuppli C, Kendal RL, Hockings K. 2019. Cultural change in animals: a flexible behavioural adaptation to human disturbance. Palgrave Commun. 5(1):1-9.

Gursky-Doyen S, Supriatna J. 2010. Indonesian Primates. New York: Springer Science.

Hadi I, Suryobroto B, Perwitasari-Farajallah D. 2007. Food Preference of Semi-Provisioned Macaques Based on Feeding Duration and Foraging Party Size. HAYATI J Biosci. 14(1):13-17.

Hidayat A, Rizaldi R, Nurdin J. 2019. Jaringan Sosial (Social Network) Antar Jantan Monyet Ekor Panjang (Macaca fascicularis) Di Gunung Meru, Padang, Sumatera Barat. J Biol UNAND. 7(1):14-20.

Hockings KJ, McLennan MR. 2012. From forest to farm: Systematic review of cultivar feeding by chimpanzees-management implications for wildlife in anthropogenic landscapes. PLoS One. 7(4):e33391.

Ilham K, Rizaldi, Nurdin J, Tsuji Y. 2017. Status of urban populations of the long-tailed macaque (Macaca fascicularis) in West Sumatra, Indonesia. Primates. 58(2):295-305.

Ilham K, Rizaldi, Nurdin J, Tsuji Y. 2018. Effect of Provisioning on the Temporal Variation in the Activity Budget of Urban Long-Tailed Macaques (Macaca fascicularis) in West Sumatra, Indonesia. Folia Primatol. 89(5):347-356.

Iqbal A, Qudoos A, Cetingul iS, Shah SRA, Bayram I. 2019. Looking at Some Animal Feeds with Respect to Halal Concept. J Anim Sci Prod. 2(1):46-53.

Jefferies RL, Rockwell RF, Abraham KF. 2004. Agricultural food subsidies, migratory connectivity and large-scale disturbance in arctic coastal systems: a case study. Integr Comp Biol. 44(2):130-9.

Kan CA, Meijer GAL. 2007. The risk of contamination of food with toxic substances present in animal feed. Anim Feed Sci Technol. 133(1-2):84-108.

Koda H, Oyakawa C, Nurulkamilah S, Rizaldi, Sugiura H, Bakar A, Masataka N. 2012. Male replacement and stability of territorial boundary in a group of agile gibbons (Hylobates agilis agilis) in West Sumatra, Indonesia. Primates. 53(4):327-332.

Korkerd S, Wanlapa S, Puttanlek C, Uttapap D, Rungsardthong V. 2015. Expansion and functional properties of extruded snacks enriched with nutrition sources from food processing by-products. J Food Sci Technol. 53(1):561-570.

Mardiah A, Rizaldi R, Novarino W. 2015. Agresi Provokasi dan Non-Provokasi pada Monyet Ekor Panjang (Macaca fascicularis, Raffles 1821) Terhadap Pengunjung di Kawasan Gunung Meru. $J$ Biol Unand. 4(4):258.

Maréchal L, Semple S, Majolo B, MacLarnon A. 2016. Assessing the Effects of Tourist Provisioning on the Health of Wild Barbary Macaques in Morocco. PLoS One. 11(5):e0155920.

Mohd Ashraf A, Abd Rahman F. 2018. Halalan Toyyiban Poultry Feed: an Appraisal from the Maqasid Shariah Perspective. Int J Eng Technol. 7(3.21):306.

Nasution EK, Rukayah S. 2018. Daily Activities of Long Tail Monkeys (Macaca fascicularis Raffles) in Cikakak Tourist Resort Wangon Banyumas (a Conservation Effort). In: SEA+ Conf Biodivers Biotechnol 2018. Purwokerto, Indonesia; p. 1-5.

Nila S, Suryobroto B, Widayati KA. 2014. Dietary Variation of Long Tailed Macaques (Macaca fascicularis) in Telaga Warna, Bogor, West Java. HAYATI J Biosci. 21(1):8-14.

Quantaniah NA, Noreina, Syakinah N. 2013. Selecting Halal Food: A Comparative Study Of The Muslim And Non Muslim Malaysian Student Consumer. In: 2nd Int Conf Technol Manag, Bus 
Entrep. Melacca, Malaysia; p. 438-453.

Randeree K. 2019. Challenges in halal food ecosystems: the case of the United Arab Emirates. $\mathrm{Br}$ Food J. 121(5):1154-1167.

Richard AF, Goldstein SJ, Dewar RE. 1989. Weed macaques: The evolutionary implications of macaque feeding ecology. Int J Primatol. 10(6):569-594.

Rizaldi, Watanabe K. 2008. Successive aggression: Another pattern of polyadic aggressive interactions in a captive group of Japanese macaques. Am J Primatol. 70(4):349-355.

Rizaldi, Watanabe K. 2010. Early development of peer dominance relationships in a cap-tive group of Japanese macaques Macaca fuscata. Curr Zool. 56(2):190-197.

Rowe N, Myers M. 2016. All the World's Primates. Rhode Island: Pogonias Press.

Sapkota AR, Lefferts LY, McKenzie S, Walker P. 2007. What do we feed to food-production animals? A review of animal feed ingredients and their potential impacts on human health. Environ Health Perspect. 115(5):663-670.

Sengupta A, Radhakrishna S. 2018. The Hand That Feeds the Monkey: Mutual Influence of Humans and Rhesus Macaques (Macaca mulatta) in the Context of Provisioning. Int J Primatol. 39(5):817-830.

Sha JCM, Hanya G. 2013. Diet, activity, habitat use, and ranging of two neighboring groups of foodenhanced long-tailed macaques (Macaca fascicularis). Am J Primatol. 75(6):581-592.

Strier KB. 2017. Primate Behavioral Ecology. 5th Edition. New York: Routledge.

Tsuji Y, Ilham K. 2021. Studies on primate crop feeding in Asian regions: A review. Mammal Study. 46(2):1-17.

Vávra J, Daněk P, Jehlička P. 2018. What is the contribution of food self-provisioning towards environmental sustainability? A case study of active gardeners. J Clean Prod. 185:1015-1023.

Verstraete F. 2013. Risk management of undesirable substances in feed following updated risk assessments. Toxicol Appl Pharmacol. 270(3):230-247. 